\title{
Soil fertility status of coconut and arecanut growing soils
}

\author{
R. Vasundhara*, N.B. Prakash ${ }^{1}$, K.S. Anil Kumar, Rajendra Hegde and S. Dharumarajan \\ ICAR-National Bureau of Soil Survey and Land Use Planning, Bengaluru-560 024, Karnataka, India \\ ${ }^{1}$ University of Agricultural Sciences, Bengaluru-560 065, Karnataka, India
}

(Manuscript Received: 24-08-2020, Revised: 20-04-2021, Accepted: 28-05-2021)

\begin{abstract}
The present study was undertaken to assess the soil fertility status of major coconut and arecanut growing soils in different agro-climatic conditions of Karnataka state, India. Based on the agro-climate variability, 30 typical soil pedons representing five different agro-climatic zones (ACZs) of Karnataka, namely, eastern dry zone (EDZ), southern dry zone (SDZ), southern transitional zone (STZ), hilly zone (HZ), and coastal zone (CZ), were studied for their physicochemical properties. The study revealed that soils of semi-arid (EDZ and SDZ) and sub-humid (STZ) zones have near neutral to moderately alkaline reaction and humid region soils (coastal and hilly zones) have high acidity. The soils are non-saline with low cation exchange capacity. Greater soil organic carbon was recorded in arecanut soils than coconut under all ACZs except the coastal zone. The major nutrients status of the soil samples indicated that the available nitrogen is low in all the pedons; the pooled data of available nitrogen content was higher in arecanut $\left(166.3 \mathrm{~kg} \mathrm{ha}^{-1}\right)$ than coconut $\left(152.6 \mathrm{~kg} \mathrm{ha}^{-1}\right)$, and hilly zone soils recorded higher available nitrogen. A wide range of available $\mathrm{P}_{2} \mathrm{O}_{5}$ was noticed in coconut and arecanut soils, ranging from 1.0 to $64.2 \mathrm{~kg} \mathrm{ha}^{-1}$. The coconut soils $\left(11.5 \mathrm{~kg}^{-1}\right)$ recorded higher available $\mathrm{P}_{2} \mathrm{O}_{5}$ than arecanut soils $\left(9.62 \mathrm{~kg} \mathrm{ha}^{-1}\right)$ when data were pooled. The soils were low to medium in available potassium, and a higher available $\mathrm{K}_{2} \mathrm{O}$ content was recorded in arecanut soils $\left(151.7 \mathrm{~kg} \mathrm{ha}^{-1}\right)$ compared to coconut $\left(110.1 \mathrm{~kg} \mathrm{ha}^{-1}\right)$. The available $\mathrm{K}_{2} \mathrm{O}$ ranged from 66.8 to $511.7 \mathrm{~kg} \mathrm{ha}^{-1}$ in the surface and 37.6 to $461.2 \mathrm{~kg} \mathrm{ha}^{-1}$ in sub-surface soils.
\end{abstract}

Keywords: Arecanut, agro-climatic zone, coconut, major nutrients, pedons, soil fertility

\section{Introduction}

Arecanut (Areca catechu L.) and coconut (Cocos nucifera L.) are predominant perennial plantation crops in south India. Cultivation of these palms in India also has a rich diversity and varied history, with each crop having its own distinct historical and economic context of development. Karnataka is one of the major producers of plantation crops. Coconut and arecanut are cultivated in different agro-climatic regions in Karnataka (Singh et al., 2013) under diverse climatic conditions and soil types. Due to variation in environmental conditions and management, the productivity of these crops also varies under different agro-climatic zones (ACZs). Soil fertility is one factor that limits the productivity of these crops, mainly influenced by the inherent capacity of the soil. The factors which influence soil fertility are mineral composition, soil $\mathrm{pH}$, soil texture, organic matter and cation exchange capacity (CEC). To understand palm productivity in a particular region or climate, an understanding of soil fertility status is essential. Maintaining soil fertility is highly important to sustain the yield of arecanut (Bhat and Sujatha, 2014).

Knowing the inherent capacity of soils to provide nutrients is an important crop nutrient prerequisite to decide the extent of organic residues required, i.e., the manures and fertilizers to be applied per palm to obtain a better yield. Hence, the present study was undertaken to understand the fertility levels of soils in arecanut and coconut growing areas under different agro-climatic conditions of Karnataka to deliver soil quality information to achieve sustainable yields. This information will also guide the balanced use of

*Corresponding Author: vasundharagowda@gmail.com 
fertilizer and implementation of cropping pattern as a component crop in plantation-based systems under varied climatic conditions.

\section{Materials and methods}

Soil profiles were excavated in coconut and arecanut plantations covering five different agroclimatic zones (ACZs), with varying rainfall, topography, soil type and climatic characteristics, including cropping patterns. The study location represents five $\mathrm{ACZs}$, covering major production centres of arecanut and coconut plantations of Karnataka. Three profiles from each of these five ACZs were selected by recording GPS points (Fig. 1) for the study, and the location details are mentioned in Table 1. The soil profiles were dug to a depth of $120 \mathrm{~cm}$. The site for sampling was representative of the area. The soil profiles were examined by demarcating different horizons based on colour, texture and structure. The details such as depth, colour, texture and structure were recorded in standard proforma for soil profile description. The list of profile samples collected from different ACZs and the details are presented in Table 1.

One hundred seventy-six soil samples representing 30 soil profiles were drawn at different depths depending upon horizon distribution. A portion of each of the soil samples was air-dried, ground in a wooden pestle with mortar and passed through a $2 \mathrm{~mm}$ stainless steel sieve for determining various soil properties. Electrical conductivity and pH were determined by standard methods (Jackson, 1973). Easily oxidizable organic carbon was estimated according to the wet oxidation method (Walkley and Black, 1934). Available nitrogen was estimated by the alkaline permanganate method (Subbiah and Asija, 1956). The soil samples were both in the acidic and alkaline range. Hence both Olsen's reagent (for neutral and alkaline soils) and Bray's reagent (for acid soils) were used for extraction. The phosphorus content in the soil extract was determined by blue colour formed by the ascorbic acid-molybdate complex, and the colour intensity was read at $660 \mathrm{~nm}$ using a spectrophotometer (Jackson, 1973). The exchangeable potassium was extracted with neutral normal ammonium acetate from a known quantity of soil. The filtered extract was fed to a flame photometer for measuring available potassium content (Page et al., 1982).

\section{Site description}

In Karnataka, these plantation crops are grown in the eastern dry zone (EDZ), southern dry zone (SDZ), southern transitional zone (STZ), hilly zone (HZ), and coastal zone (CZ). EDZ and SDZ experience hot moist, semi-arid climate, recording average annual rainfall of $750 \mathrm{~mm}$ to $850 \mathrm{~mm}$,

Table 1. Details of soil profile samples collected from arecanut and coconut plantations representing different agro-climatic zones of Karnataka

\begin{tabular}{lll}
\hline & Location (Coconut) & Location (Arecanut) \\
\hline Eastern dry zone & Gubbi & Hebbur, Tumkur \\
& Kanakuppe, Tumkur & Borogowdana Palya, Kunigal \\
& Hottigana Hosahali Channapattana & Hesaraghatta \\
\hline Southern dry zone & Thamadahalli, Chamarajanagar & T. Narasipura \\
& Kadaballi Nelamangala & Cholanahalli Channarayapattana \\
\hline Southern transitional zone & V.C Farm, Mandya & Channegowdana Doddi, Maddur \\
& Bhadravathi & Tarikere \\
& Gurupura Hunusur & H D Kote \\
\hline Hilly zone & Muddanahalli Village, Hassan & Hosur Alur Hassan \\
\hline Coastal zone & Mavinakere, Kalasa & Sukkamatti, Sringeri \\
& Manase, Sringeri & Bidharahalli, Mudigere \\
& ARS Mudigere & Sirsi \\
\hline
\end{tabular}


length of dry period $>150$ days. STZ has a subhumid climate receiving $950 \mathrm{~mm}$ rainfall, length of dry period-120 days. Hilly and coastal zone have hot, humid climate receiving an annual average rainfall of $>1500 \mathrm{~mm}$ and $4500 \mathrm{~mm}$, respectively, with 90 days of dry period. The soil temperature regime is isohyperthermic for all the studied soils as they have a difference of less than $5^{\circ} \mathrm{C}$ between mean summer temperature and mean winter temperatures at a depth of $50 \mathrm{~cm}$ and a mean annual soil temperature of $22^{\circ} \mathrm{C}$ or higher.

\section{Results and discussion}

\section{Soil reaction and electrical conductivity}

Soil nutrient availability was directly influenced by soil $\mathrm{pH}$. Results of soil $\mathrm{pH}$ revealed that the soil $\mathrm{pH}$ was higher in all the agroclimatic zones except in $\mathrm{HZ}$ and $\mathrm{CZ}$ of the study area. (Table 2 and Fig. 2).

Soil $\mathrm{pH}$ ranged from 5.13-8.34 in coconut to 4.99-8.32 in arecanut soils. The $\mathrm{pH}$ of EDZ, SDZ, STZ, HZ and CZ varied from 7.46-7.79, 8.05-8.34, 6.79-7.58, 5.15-6.12 and 5.13-5.25, respectively, in coconut soils, whereas in arecanut, the soil $\mathrm{pH}$ varied from 7.55-7.91, 8.12- 8.32, 7.72-7.85, 4.995.34 and 5.43-5.65, respectively.

Irrespective of crop, a very low $\mathrm{pH}$ range was recorded in $\mathrm{HZ}$ and $\mathrm{CZ}$ soil pedons, while high $\mathrm{pH}$ was observed in SDZ soil pedons (Fig. 2a \& b). Electrical conductivity in EDZ, SDZ, STZ, HZ and $\mathrm{CZ}$ ranged from $0.155-0.212,0.115-0.18,0.135$ $0.15,0.043-0.05$, and $0.03-0.232 \mathrm{dS} \mathrm{m}^{-1}$ in coconut soils. In arecanut soils, EC ranged from 0.185-0.253, 0.151-0.207, 0.155-0.251, 0.03-0.0.52 and 0.022-0.031 $\mathrm{dS} \mathrm{m} \mathrm{m}^{-1}$, respectively.

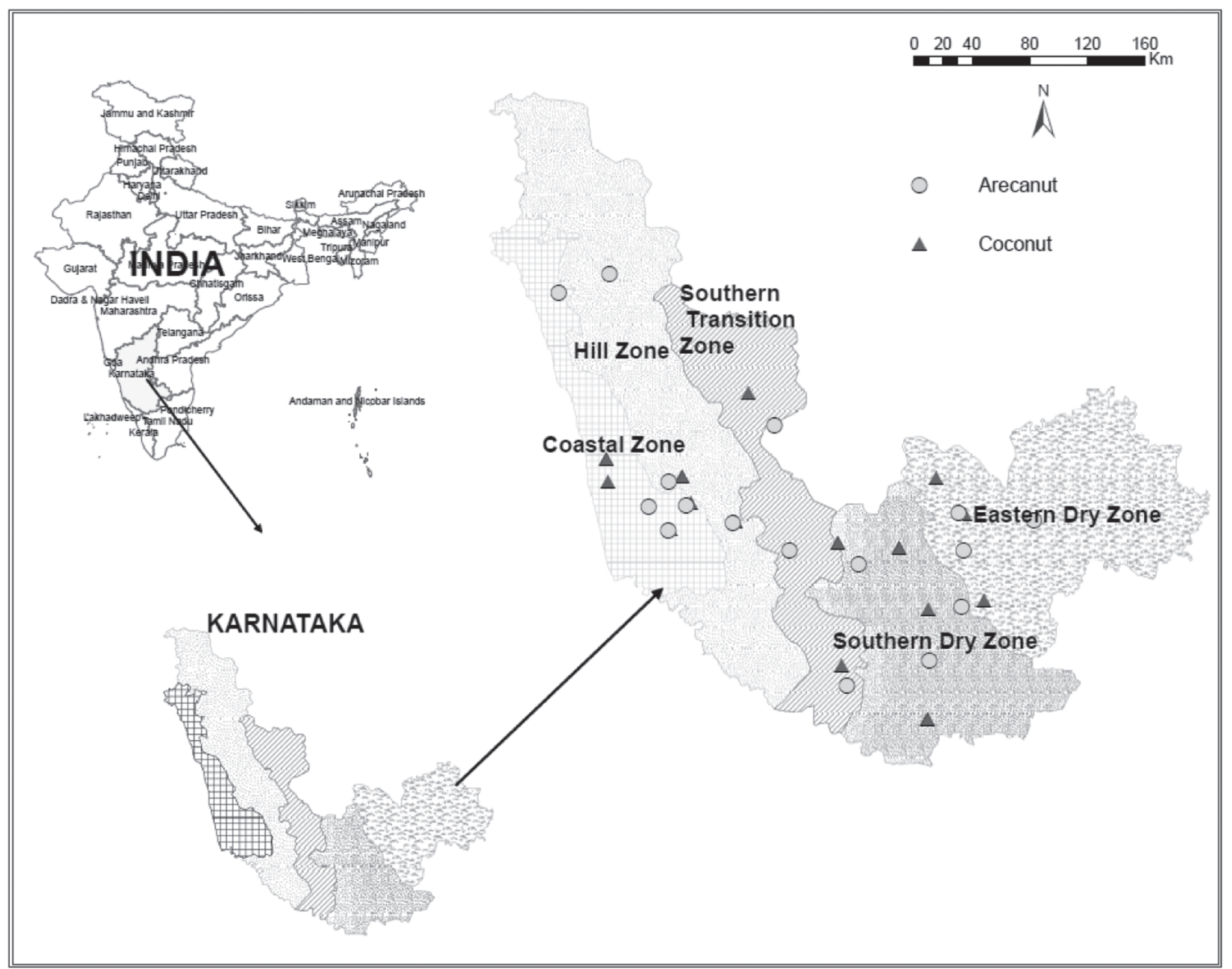

Fig. 1. Location map of the study area 
Analysis of coconut and arecanut soils representing different agro-climatic zones of Karnataka revealed that EDZ, SDZ, and STZ soils were slight to moderately alkaline, $\mathrm{HZ}$ and $\mathrm{CZ}$ were acidic, and STZ were neutral in pH (Fig. 2 a and b). Electrical conductivity values indicated the nonsaline nature of the soils of the study area.

Moderate to slightly acidic soil reaction in $\mathrm{HZ}$ and $\mathrm{CZ}$ soils are mainly due to the heavy rainfall, which causes leaching of bases, thereby reducing the soil pH. Badrinath et al. (1995) reported that southern parts (CZ and HZ) of Karnataka were distributed with acidic soil, affecting crop yields. Slightly to moderately alkaline soil reaction in other areas was due to accumulation of basic salts from the weathered parent material.

\section{Soil organic carbon and cation exchange capacity (CEC)}

Soils of arecanut plantations recorded higher organic carbon content compared to coconut. An increase in organic carbon content noticed in arecanut soils may be due to well managed mixed farming system, which produces higher recyclable biomass from component crops, and higher biomass turnover in arecanut enhances the carbon in soil compared to coconut. Arecanut has a higher recycling potential of organic wastes (Sujatha et al., 2015). Arecanut also equally contributes greater

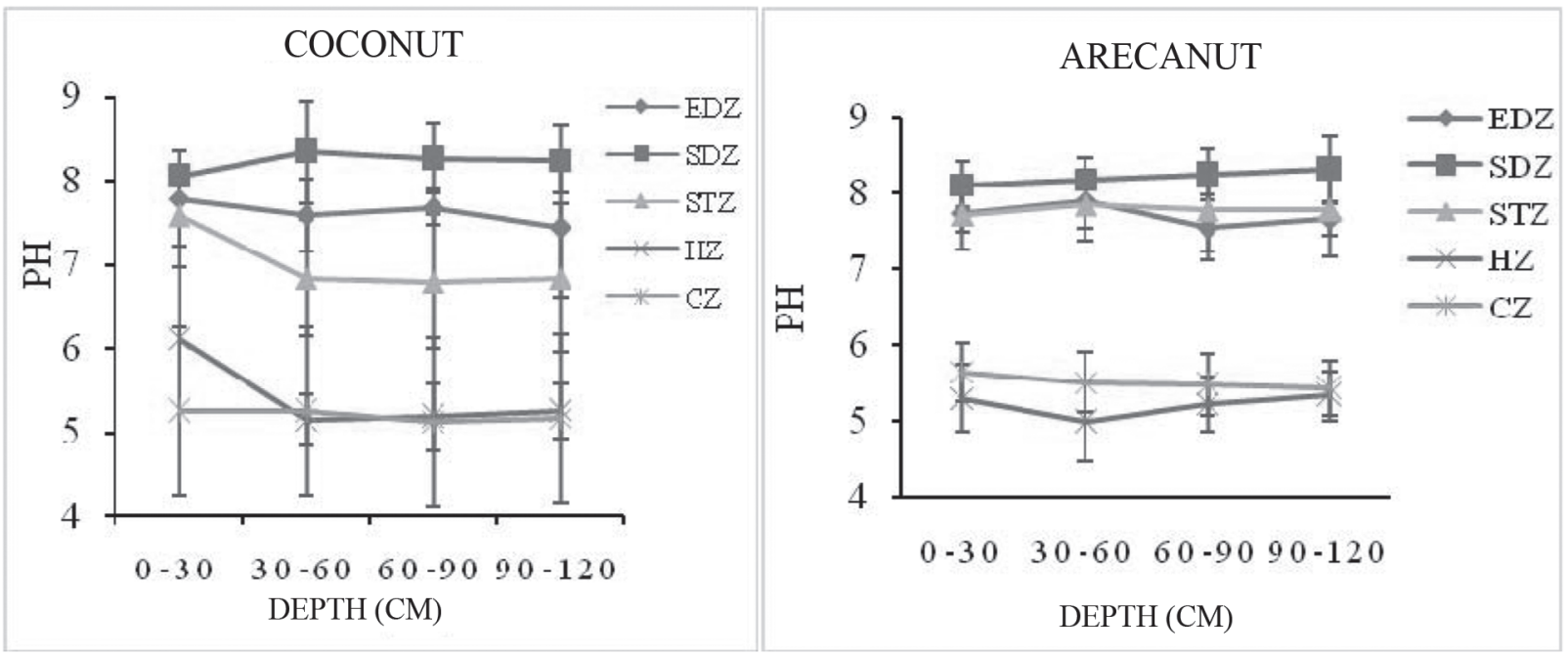

Fig. 2. Soil reaction-in different depths of coconut and arecanut plantations across different agro-climatic zones

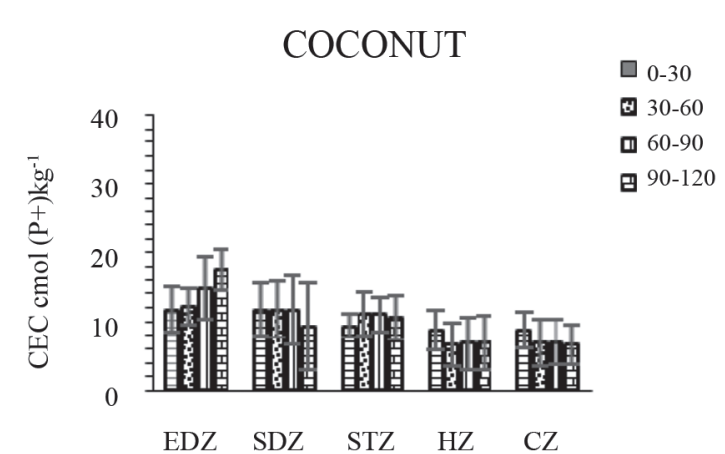

Agroclimatic zone

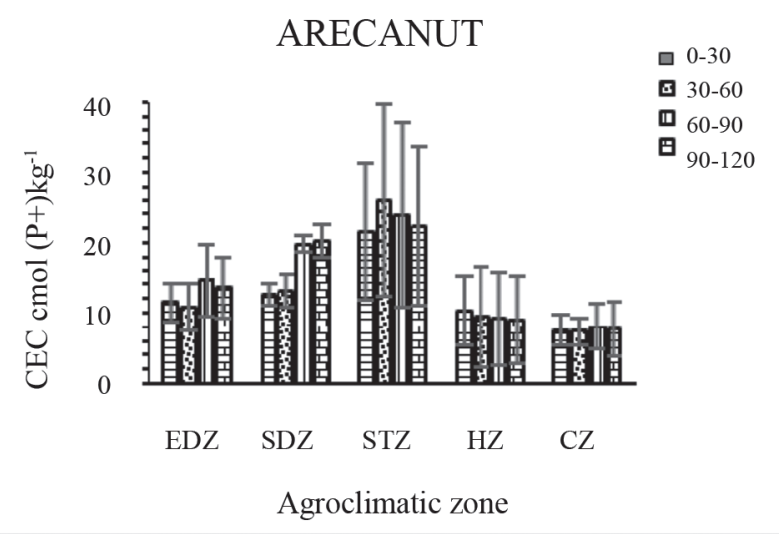

Fig. 3. CEC in different depths of coconut and arecanut plantations across different agro-climatic zones 


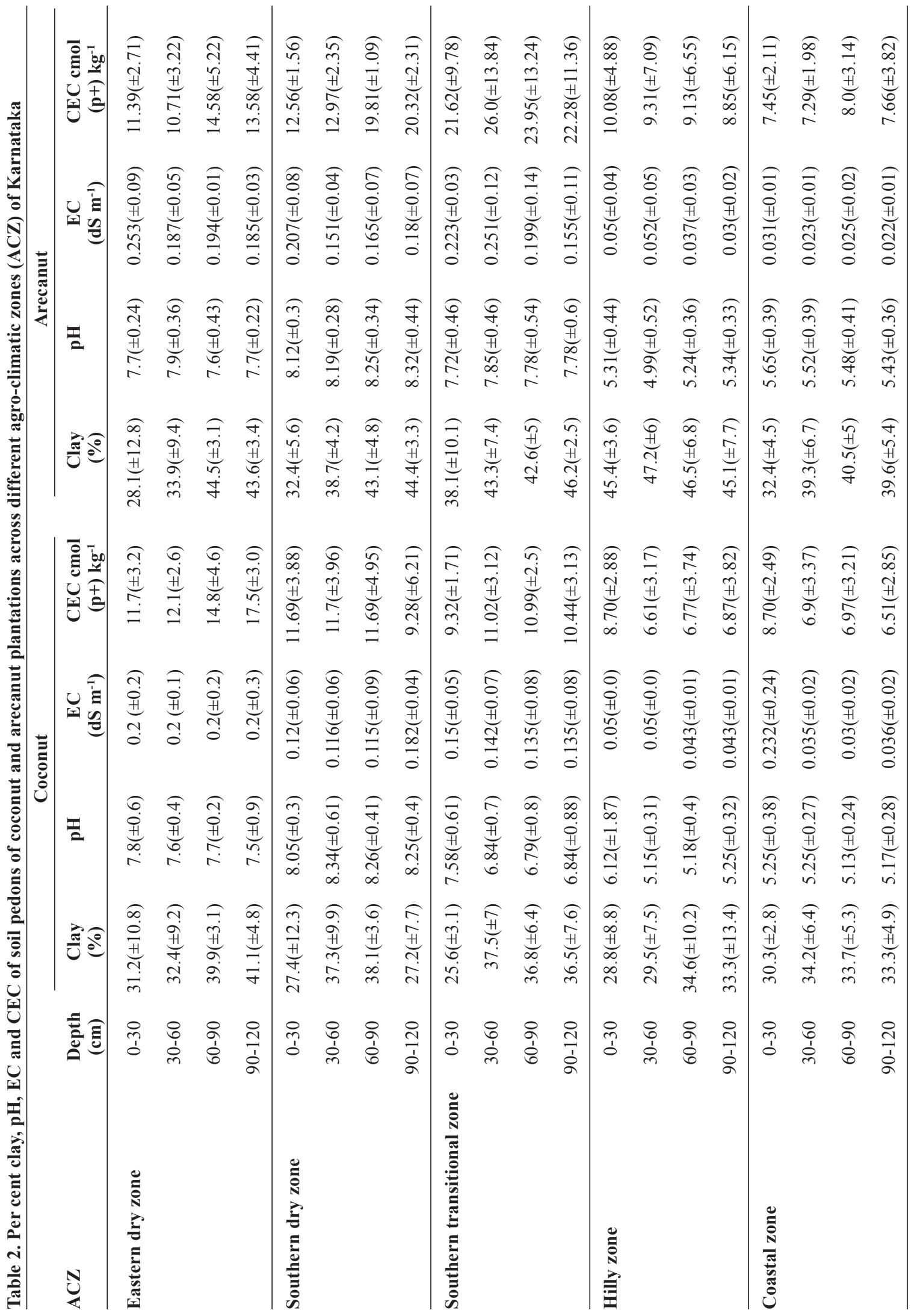


Table 3. Available nitrogen $\left(\mathrm{kg} \mathrm{ha}^{-1}\right)$ of soil pedons of coconut and arecanut plantations in different agro-climatic zones (ACZ) of Karnataka

\begin{tabular}{|c|c|c|c|c|c|c|c|}
\hline \multicolumn{2}{|l|}{ Depth (cm) } & EDZ & SDZ & STZ & $\mathrm{HZ}$ & $\mathbf{C Z}$ & $\begin{array}{c}\text { Crop } \times \text { depth } \\
\text { mean } \\
\end{array}$ \\
\hline \multicolumn{8}{|l|}{ Coconut } \\
\hline \multicolumn{2}{|l|}{$0-30$} & $192.9( \pm 83.4)^{\mathrm{a}}$ & $164.5( \pm 41.2)$ & $134.8( \pm 15.4)$ & $179.5( \pm 68.6)$ & $239.7( \pm 28.4)$ & 182.3 \\
\hline \multicolumn{2}{|l|}{$30-60$} & $168.9( \pm 51.2)^{\mathrm{ab}}$ & $179.3( \pm 110.6)$ & $175.8( \pm 39.6)$ & $149.1( \pm 88.2)$ & $213.9( \pm 51.3)$ & 177.4 \\
\hline \multicolumn{2}{|l|}{$60-90$} & $110.9( \pm 35.1)^{\mathrm{bc}}$ & $98.1( \pm 33.6)$ & $141.5( \pm 43.7)$ & $123.9( \pm 119.8)$ & $164.7( \pm 91.2)$ & 127.8 \\
\hline \multicolumn{2}{|l|}{$90-120$} & $102.3( \pm 62.6)^{\mathrm{c}}$ & $100.9( \pm 92.2)$ & $115( \pm 50.4)$ & $125.4( \pm 122.1)$ & $170.0( \pm 82.5)$ & 122.7 \\
\hline \multicolumn{2}{|c|}{ Coconut $\times$ zone mean } & 143.8 & 135.7 & 141.8 & 144.5 & 197.1 & 152.6 \\
\hline \multicolumn{2}{|l|}{$\operatorname{SEm} \pm$} & 17.2 & 34.7 & 17.8 & 16.6 & 20.1 & \\
\hline \multicolumn{2}{|l|}{$\mathrm{CD}$ at 0.05} & 59.4 & NS & 54.0 & 50.7 & 61.0 & \\
\hline \multicolumn{8}{|l|}{ Arecanut } \\
\hline \multicolumn{2}{|l|}{$0-30$} & $158.4( \pm 64.4)$ & $236.6( \pm 70.2)$ & $223.7( \pm 18)^{\mathrm{a}}$ & $263.6( \pm 38.8)$ & $189.9( \pm 86.1)$ & 214.4 \\
\hline \multicolumn{2}{|l|}{$30-60$} & $160.8( \pm 28.3)$ & $185.0( \pm 33)$ & $188.4( \pm 52.2)^{\mathrm{ab}}$ & $235.3( \pm 135.9)$ & $158.5( \pm 42.4)$ & 185.6 \\
\hline \multicolumn{2}{|l|}{$60-90$} & $141.1( \pm 68.9)$ & $139.9( \pm 97)$ & $143.7( \pm 32.3)^{\mathrm{bc}}$ & $207.3( \pm 112.1)$ & $131.2( \pm 39.5)$ & 152.7 \\
\hline \multicolumn{2}{|l|}{$90-120$} & $116.2( \pm 24.6)$ & $86.2( \pm 51.4)$ & $118.8( \pm 25.8)^{\mathrm{c}}$ & $168.6( \pm 112.2)$ & $73.1( \pm 50.6)$ & 112.6 \\
\hline \multicolumn{2}{|c|}{ Arecanut $\times$ zone mean } & 144.1 & 161.9 & 168.7 & 218.7 & 138.2 & 166.3 \\
\hline \multicolumn{2}{|l|}{$\mathrm{SEm} \pm$} & 28.4 & 29.9 & 16.8 & 30.0 & 33.5 & \\
\hline \multicolumn{2}{|l|}{$\mathrm{CD}$ at 0.05} & NS & 90.1 & 58.2 & NS & 99.6 & \\
\hline \multicolumn{2}{|c|}{ Grand zone mean } & 143.9 & 148.8 & 155.2 & 181.6 & 167.6 & Depth mean \\
\hline Interactions & $\mathrm{C}$ & $\mathrm{Z}$ & $\mathrm{D}$ & $\mathrm{C} \times \mathrm{Z}$ & $\mathrm{C} \times \mathrm{D}$ & $\mathrm{Z} \times \mathrm{D}$ & $\mathrm{C} \times \mathrm{Z} \times \mathrm{D}$ \\
\hline $\mathrm{SEm} \pm$ & 9.1 & 14.3 & 12.8 & 20.2 & 18.1 & 28.6 & 40.5 \\
\hline $\mathrm{CD}$ at 0.05 & NS & NS & 36.1 & 57.1 & NS & NS & NS \\
\hline
\end{tabular}

The results are shown as the mean $( \pm$ SD). Values with the same letters within columns (soil depths) are not significantly different at $\mathrm{P}<0.05$. C:Crop, Z:Zone, D:Depth, EDZ:eastern dry zone, SDZ:southern dry zone, STZ:southern transition zone, HZ:hilly zone and $\mathrm{CZ}$ :coastal zone

biomass (8.5-18 $\mathrm{t} \mathrm{ha}^{-1}$ depending on the age of arecanut crop) like other palms such as coconut (12-18 $\mathrm{t} \mathrm{ha}^{-1}$ ) and oil palm (14-15 $\mathrm{t} \mathrm{ha}^{-1}$ ) owing to high population density per unit area. Among the ACZs, HZ soils recorded the highest organic carbon content, which might be due to clay mineralogy, clay fraction and biochemical environment of the soil such as $\mathrm{pH}$, higher rainfall, its intensity and distribution in a year, which favours higher production of biomass. It is very much evidenced (Table 4) that the clay content of the hilly zone was higher compared to other ACZ pedons. Higher accumulation of soil organic carbon in hilly and mountain areas can be attributed to favourable soil-climate environment (Fig. 4).

The results revealed that the CEC of 176 soils representing 30 soil pedons ranged from 2.53 to 38.12 $\mathrm{cmol}\left(\mathrm{p}^{+}\right) \mathrm{kg}^{-1}$. Lower CEC was recorded in $\mathrm{CZ}$, while higher CEC was observed in STZ soil pedons (Fig. 3). Soils collected from coconut plantations recorded low CEC, ranging from 6.51 to $17.45 \mathrm{cmol}$ $\left(\mathrm{p}^{+}\right) \mathrm{kg}^{-1}$. In arecanut soils, CEC ranged from 7.29 to $26.0 \mathrm{cmol}\left(\mathrm{p}^{+}\right) \mathrm{kg}^{-1}$ (Table 2 and Fig. 3).

CEC was higher in STZ ranging from 9.32 to $26.0 \mathrm{cmol}\left(\mathrm{p}^{+}\right) \mathrm{kg}^{-1}$ followed by SDZ (9.28 to 21.32 $\left.\operatorname{cmol}\left(\mathrm{p}^{+}\right) \mathrm{kg}^{-1}\right)$ and $\operatorname{EDZ}$ (10.71 to $\left.17.45 \mathrm{cmol}\left(\mathrm{p}^{+}\right) \mathrm{kg}^{-1}\right)$. 
Table 4. Available $\mathrm{P}_{2} \mathrm{O}_{5}\left(\mathrm{~kg} \mathrm{ha}^{-1}\right)$ in soil pedons of coconut and arecanut plantations in different agro-climatic zones (ACZ) of Karnataka

\begin{tabular}{|c|c|c|c|c|c|c|c|}
\hline \multicolumn{2}{|l|}{ Depth (cm) } & EDZ & SDZ & STZ & $\mathrm{HZ}$ & $\mathbf{C Z}$ & $p \times$ depth mean \\
\hline \multicolumn{8}{|l|}{ Coconut } \\
\hline \multicolumn{2}{|l|}{$0-30$} & $16.5( \pm 11.1)$ & $8.3( \pm 5.3)$ & $64.3( \pm 35.7)^{\mathrm{a}}$ & $4.1( \pm 3.6)$ & $15.9( \pm 20.0)$ & 21.8 \\
\hline \multicolumn{2}{|l|}{$30-60$} & $12.1( \pm 9.4)$ & $7.9( \pm 4.2)$ & $15.0( \pm 9.4)^{\mathrm{b}}$ & $1.4( \pm 0.5)$ & $12.8( \pm 16.1)$ & 9.8 \\
\hline \multicolumn{2}{|l|}{$60-90$} & $9.2( \pm 10.6)$ & $4.2( \pm 2.8)$ & $11.9( \pm 6.6)^{b}$ & $1.3( \pm 0.6)$ & $10.4( \pm 13.6)$ & 7.4 \\
\hline \multicolumn{2}{|l|}{$90-120$} & $6.2( \pm 5.1)$ & $4.7( \pm 2.8)$ & $11.5( \pm 5.6)^{b}$ & $1.0( \pm 0.0)$ & $10.4( \pm 13.6)$ & 6.8 \\
\hline \multicolumn{2}{|l|}{ Coconut $\times$ zone mean } & 11.0 & 6.3 & 25.7 & 2.0 & 12.4 & 11.5 \\
\hline \multicolumn{2}{|l|}{$\operatorname{SEm} \pm$} & 2.3 & 1.1 & 8.7 & 1.0 & 1.8 & \\
\hline \multicolumn{2}{|l|}{ CD at 0.05} & 7.1 & 3.4 & 30.2 & NS & NS & \\
\hline \multicolumn{8}{|l|}{ Arecanut } \\
\hline \multicolumn{2}{|l|}{$0-30$} & $17.4( \pm 6.87)^{\mathrm{a}}$ & $33.1( \pm 28.09)$ & $20.9( \pm 7.75)^{\mathrm{a}}$ & $11.5( \pm 8.38)$ & $5.9( \pm 7.5)$ & 17.8 \\
\hline \multicolumn{2}{|l|}{$30-60$} & $5.7( \pm 2.13)^{\mathrm{b}}$ & $19.5( \pm 16.77)$ & $3.8( \pm 1.99)^{\mathrm{b}}$ & $8.0( \pm 9.17)$ & $3.0( \pm 0.6)$ & 8.0 \\
\hline \multicolumn{2}{|l|}{$60-90$} & $7.2( \pm 4.05)^{b}$ & $10.9( \pm 11.31)$ & $3.5( \pm 2.3)^{b}$ & $7.5( \pm 8.29)$ & $3.8( \pm 0.1)$ & 6.6 \\
\hline \multicolumn{2}{|l|}{$90-120$} & $6.1( \pm 2.52)^{b}$ & $8.3( \pm 4.7)$ & $2.8( \pm 1.65)^{\mathrm{b}}$ & $8.9( \pm 10.75)$ & $4.6( \pm 1.2)$ & 6.1 \\
\hline \multicolumn{2}{|l|}{ Arecanut $\times$ zone mean } & 9.1 & 18.0 & 7.8 & 9.0 & 4.3 & 9.6 \\
\hline \multicolumn{2}{|l|}{$\operatorname{SEm} \pm$} & 2.1 & 4.8 & 2.1 & 4.2 & 2.2 & \\
\hline \multicolumn{2}{|l|}{$\underline{\mathrm{CD}}$ at 0.05} & 7.3 & 15.2 & 7.1 & NS & NS & \\
\hline \multicolumn{2}{|l|}{ Grand zone mean } & $10.1^{b c}$ & $12.1^{\text {ab }}$ & $16.7^{\text {a }}$ & $5.5^{\mathrm{c}}$ & $8.3^{b}$ & Depth mean \\
\hline Interactions & $\mathrm{C}$ & $\mathrm{Z}$ & $\mathrm{D}$ & $\mathrm{C} \times \mathrm{Z}$ & $\mathrm{C} \times \mathrm{D}$ & $\mathrm{Z} \times \mathrm{D}$ & $\mathrm{C} \times \mathrm{Z} \times \mathrm{D}$ \\
\hline $\operatorname{SEm} \pm$ & 9.1 & 14.3 & 12.8 & 20.2 & 18.1 & 28.6 & 40.5 \\
\hline CD at 0.05 & NS & NS & 36.1 & 57.1 & NS & NS & NS \\
\hline
\end{tabular}

The results are shown as the mean $( \pm \mathrm{SD})$. Values with the same letters within columns (soil depths) are not significantly different at $\mathrm{P}<0.05$. C:Crop, Z:Zone,D:Depth, EDZ: eastern dry zone, SDZ: southern dry zone, STZ: southern transition zone, HZ: hilly zone and $\mathrm{CZ}$ : coastal zone

Lower CEC was observed in $\mathrm{HZ}$ and $\mathrm{CZ}$, ranging

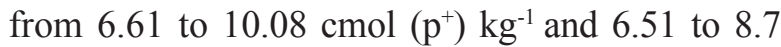
$\mathrm{cmol}\left(\mathrm{p}^{+}\right) \mathrm{kg}^{-1}$, respectively. Low CEC in $\mathrm{HZ}$ and $\mathrm{CZ}$ due to the presence of kaolinite minerals. Heavy rainfall in these regions enhanced $\mathrm{K}$ leaching, leading to lesser fixation of $\mathrm{K}$ in sites. Normally, kaolinite minerals soils hold a lesser amount of available and exchangeable K (Martin and Sparks, 1985). Organic carbon and clay content play a major role in influencing CEC. Organic carbon content decreased with depth in all soils; still, CEC showed an increasing trend indicating the mineralogy of the soils, which probably had a larger role in regulating CEC in these soils than the organic matter. Saikh et al. (1998) observed a poor correlation between CEC and organic carbon in ferruginous soils under deciduous forest and attributed this change in CEC to mineralogy.

\section{Available major nutrients status in coconut and arecanut plantations}

\section{Available nitrogen}

The average content of available nitrogen in coconut and arecanut soils varied from 98.1 to 239.7 $\mathrm{kg} \mathrm{ha}^{-1}$ and 73.1 to $263.6 \mathrm{~kg} \mathrm{ha}^{-1}$, respectively. The mean available nitrogen content was higher in arecanut (166.3 kg ha $\left.{ }^{-1}\right)$ than coconut (152.6 $\left.\mathrm{kg} \mathrm{ha}^{-1}\right)$. In coconut, higher available nitrogen was observed in CZ (197.1 $\mathrm{kg} \mathrm{ha}^{-1}$ ) followed by HZ (144.5 $\left.\mathrm{kg} \mathrm{ha}^{-1}\right)$ and in arecanut, maximum available nitrogen was observed in HZ (218.7 $\left.\mathrm{kg} \mathrm{ha}^{-1}\right)$ followed by STZ (168.7 $\left.\mathrm{kg} \mathrm{ha}^{-1}\right), \operatorname{SDZ}\left(161.9 \mathrm{~kg} \mathrm{ha}^{-1}\right), \mathrm{CZ}\left(138.2 \mathrm{~kg} \mathrm{ha}^{-1}\right)$ and EDZ (144.1 $\left.\mathrm{kg} \mathrm{ha}^{-1}\right)$. Among the ACZs the available nitrogen content followed the order of $\mathrm{HZ}$ $\left(181.6 \mathrm{~kg} \mathrm{ha}^{-1}\right)>\mathrm{CZ}\left(167.6 \mathrm{~kg} \mathrm{ha}^{-1}\right)>\mathrm{STZ}(155.2$ $\left.\mathrm{kg} \mathrm{ha}^{-1}\right)>\operatorname{SDZ}\left(148.8 \mathrm{~kg} \mathrm{ha}^{-1}\right)>\operatorname{EDZ}\left(143.9 \mathrm{~kg} \mathrm{ha}^{-1}\right)$. 
The available nitrogen status in coconut and arecanut soils in different ACZs are presented in Figure 4a and Table 3. Higher available nitrogen was noticed in the surface $(0-30 \mathrm{~cm})$ and decreased with an increase in depth; a significant difference was noticed at all depths. Higher available nitrogen noticed in 0-60 $\mathrm{cm}$ depth might be due to applying chemical fertilizers and FYM, high turnover of crop residues. Bhat and Sujatha (2007) observed significantly higher mineral $\mathrm{N}$ in the arecanut+pepper crop-based system $(0-30 \mathrm{~cm}$ depth $)$ than in cocoa and clove. Organic matter recycling (OMR) was significantly higher in arecanut based cropping systems than other plantations. Higher nitrogen content in $\mathrm{HZ}$ might be due to higher biomass returns to soil (Achalu et al., 2012).

\section{Available $\mathrm{P}_{2} \mathrm{O}_{5}$}

The available $\mathrm{P}_{2} \mathrm{O}_{5}$ status in coconut and arecanut soils varied from 1.0 to $64.2 \mathrm{~kg} \mathrm{ha}^{-1}$ and 2.9 to $47.8 \mathrm{~kg} \mathrm{ha}^{-1}$, respectively. The coconut soils $\left(11.5 \mathrm{~kg} \mathrm{ha}^{-1}\right)$ recorded higher available $\mathrm{P}_{2} \mathrm{O}_{5}$ when compared to arecanut soils $\left(9.62 \mathrm{~kg} \mathrm{ha}^{-1}\right)$; however, no significant difference was noticed (Fig. 4b). The low status of available $\mathrm{P}_{2} \mathrm{O}_{5}$ in arecanut soils is attributed to higher removal than replenishment due to high nutrient demand from the main crop and component crop (Table 4).

In coconut, higher available $\mathrm{P}_{2} \mathrm{O}_{5}$ was observed in STZ (25.66 $\left.\mathrm{kg} \mathrm{ha}^{-1}\right)$ followed by CZ $\left(12.37 \mathrm{~kg} \mathrm{ha}^{-1}\right)$, EDZ (11.0 $\left.\mathrm{kg} \mathrm{ha}^{-1}\right)$, SDZ (6.27 $\mathrm{kg} \mathrm{ha}^{-1}$ ) and $\mathrm{HZ}\left(1.96 \mathrm{~kg} \mathrm{ha}^{-1}\right)$. In arecanut growing soil, available $\mathrm{P}_{2} \mathrm{O}_{5}$ followed the trend SDZ $\left(17.95 \mathrm{~kg} \mathrm{ha}^{-1}\right)>\operatorname{EDZ}\left(9.1 \mathrm{~kg} \mathrm{ha}^{-1}\right)>\mathrm{HZ}$ $\left(8.97 \mathrm{~kg} \mathrm{ha}^{-1}\right) \geq \operatorname{STZ}\left(7.75 \mathrm{~kg} \mathrm{ha}^{-1}\right)>\operatorname{CZ}\left(4.31 \mathrm{~kg} \mathrm{ha}^{-1}\right)$.

Table 5. Available $\mathrm{K}_{2} \mathrm{O}\left(\mathrm{kg} \mathrm{ha}^{-1}\right)$ in soil pedons of coconut and arecanut plantations in different agro-climatic zones (ACZ) of Karnataka

\begin{tabular}{|c|c|c|c|c|c|c|}
\hline Depth (cm) & EDZ & SDZ & STZ & $\mathrm{HZ}$ & $\mathbf{C Z}$ & depth mean \\
\hline \multicolumn{7}{|l|}{ Coconut } \\
\hline $0-30$ & $233.6( \pm 275.0)$ & $105.3( \pm 75.6)$ & $198.7( \pm 98.2)$ & $79.4( \pm 9.8)^{\mathrm{a}}$ & $125.6( \pm 68.1)^{\mathrm{a}}$ & 148.5 \\
\hline $30-60$ & $461.2( \pm 696.0)$ & $54.2( \pm 8.2)$ & $115.9( \pm 44.1)$ & $37.3( \pm 5.2)^{\mathrm{b}}$ & $75.5( \pm 37.4)^{\mathrm{ab}}$ & 148.8 \\
\hline $60-90$ & $126.8( \pm 105.4)$ & $50.7( \pm 19.0)$ & $114.3( \pm 35.6)$ & $40.3( \pm 3)^{b}$ & $60.4( \pm 35.4)^{\mathrm{b}}$ & 78.5 \\
\hline $90-120$ & $88.2( \pm 25.0)$ & $43.7( \pm 38.4)$ & $101.2( \pm 35.3)$ & $37.6( \pm 3.8)^{b}$ & $51.5( \pm 34.2)^{\mathrm{b}}$ & 64.4 \\
\hline Coconut $\times$ zone mean & 227.4 & 63.5 & 132.5 & 48.7 & 78.3 & 110.1 \\
\hline SEm \pm & 175.0 & 17.4 & 21.4 & 3.7 & 15.0 & \\
\hline CD at 0.05 & NS & 53.4 & 65.4 & 12.9 & 51.7 & \\
\hline
\end{tabular}

\begin{tabular}{|c|c|c|c|c|c|}
\hline \\
\hline \multicolumn{6}{|c|}{$250.0( \pm 101.9)^{\mathrm{a}} \quad 511.7( \pm 533.2) 188.8( \pm 135.3) \quad 66.4( \pm 31.7)$} \\
\hline $30-60$ & $70.1( \pm 28.4)$ & $136.7( \pm 77.4)^{\mathrm{c}}$ & $308.5( \pm 252.9) 118.3( \pm 96.7)$ & $56.8( \pm 32.3)$ & 138.1 \\
\hline $60-90$ & $76.9( \pm 27.3)$ & $177.1( \pm 91.8)^{\mathrm{b}}$ & $262.7( \pm 134.5) \quad 69.9( \pm 49.9)$ & $58.1( \pm 34.3)$ & 128.9 \\
\hline $90-120$ & $66.0( \pm 20.9)$ & $178.7( \pm 94.6)^{\mathrm{b}}$ & $48.4( \pm 32.3)$ & $57.2( \pm 39.7)$ & 112.5 \\
\hline Arecanut $\times$ zone mean & 83.1 & 185.6 & 323.7 & 59.6 & 151.7 \\
\hline SEm \pm & 24.4 & 15.0 & 131.7 & 12.2 & \\
\hline $\mathrm{CD}$ at 0.05 & NS & 35.9 & 91.4 & NS & \\
\hline Grand zone mean & $155.3^{a b}$ & $124.5^{b}$ & $228.1^{a}$ & $69.0^{b}$ & Depth mean \\
\hline Interactions & Z & $\mathrm{D}$ & $\mathrm{C} \times \mathrm{D}$ & $\mathrm{Z} \times \mathrm{D}$ & $\mathrm{C} \times \mathrm{Z} \times \mathrm{D}$ \\
\hline $\operatorname{SEm} \pm$ & 3.1 & 29.6 & 46.8 & 66.2 & 93.6 \\
\hline CD at 0.05 & 90.6 & 81.1 & 128.2 & NS & NS \\
\hline
\end{tabular}

The results are shown as the mean $( \pm \mathrm{SD})$. Values with the same letters within columns (soil depths) are not significantly different at $\mathrm{P}<0.05$. C:Crop, Z:Zone,D:Depth, EDZ:eastern dry zone, SDZ:southern dry zone, STZ:southern transition zone, HZ:hilly zone and CZ:coastal zone 


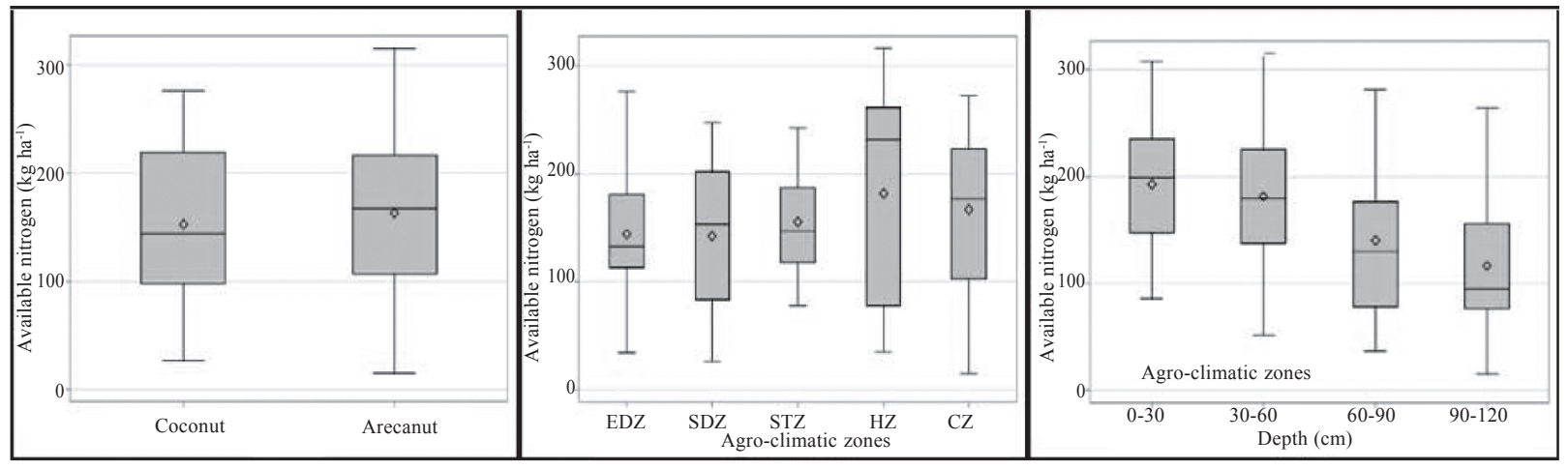

Fig. 4a. Distribution of available nitrogen $\left(\mathrm{kg} \mathrm{ha}^{-1}\right)$ in (a) coconut and arecanut plantations (b) different agro-climatic zones (c) different depths of soil pedons

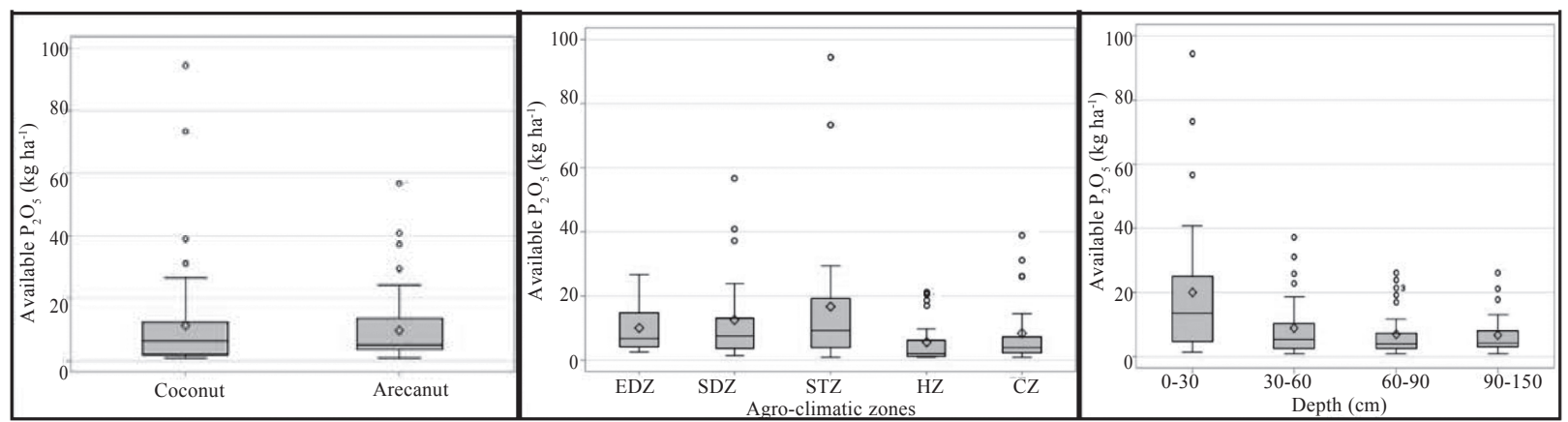

Fig. 4b. Distribution of available $\mathrm{P}_{2} \mathrm{O}_{5}\left(\mathrm{~kg} \mathrm{ha}^{-1}\right)$ in (a) coconut and arecanut plantations (b) different agro-climatic zones (c) different depths of soil pedons

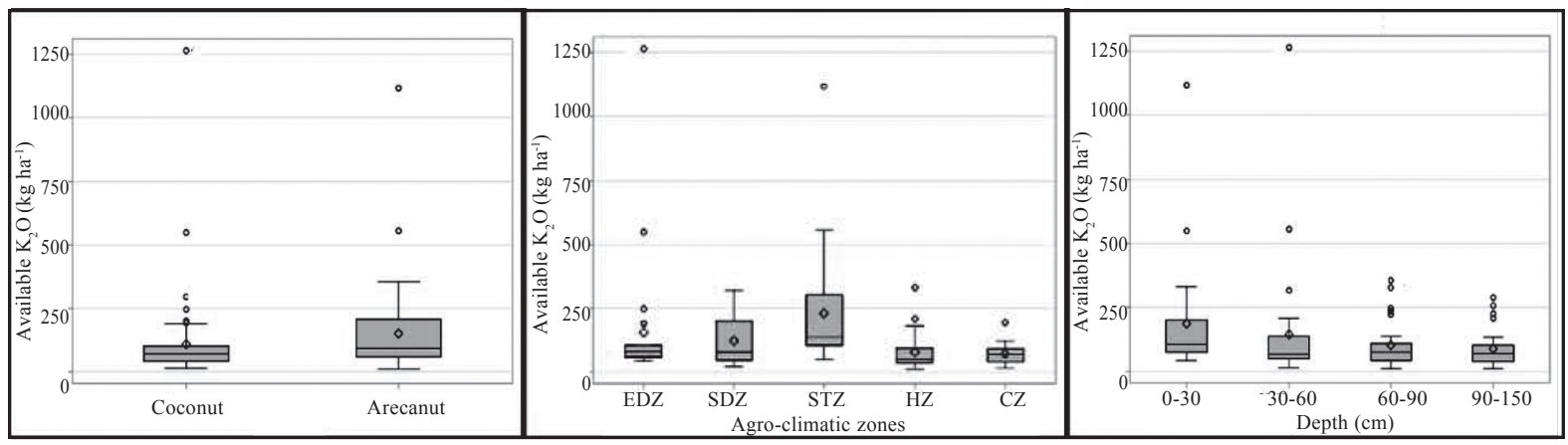

Fig. 4c. Distribution of available $\mathrm{K}_{2} \mathrm{O}\left(\mathrm{kg} \mathrm{ha}^{-1}\right)$ in (a) coconut and arecanut plantations (b) different agro-climatic zones (c) different depths of soil pedons

The pooled data of available $\mathrm{P}_{2} \mathrm{O}_{5}$ content in different ACZs were 16.70, 12.11, 10.05, 8.34 and $5.47 \mathrm{~kg} \mathrm{ha}^{-1}$ for STZ, SDZ, EDZ, CZ and HZ, respectively.

Lower available $\mathrm{P}_{2} \mathrm{O}_{5}$ content was observed in $\mathrm{HZ}$, and $\mathrm{CZ}$ attributed to the lower application of fertilizers and fixation of $\mathrm{P}$ in acidic soils of hilly and coastal zones. The low status of $\mathrm{P}$ in these regions is due to the soils rich in hydrated and amorphous oxides of $\mathrm{Fe}$ and $\mathrm{Al}$, which are potential phosphorus fixers (Perur, 1996: West et al., 1997). SDZ and EDZ zones recorded lower $\mathrm{P}_{2} \mathrm{O}_{5}$ than STZ due to the higher soil $\mathrm{pH}$ that cause $\mathrm{P}$ fixation in soil. The higher amount of available $\mathrm{P}_{2} \mathrm{O}_{5}$ in STZ might be due to the application of FYM and recommended dose of fertilizer, which enhances the 
availability in soil, and the neutral $\mathrm{pH}$ of these soils. An increase in P status was mainly attributed to the addition of FYM and chemical fertilizers in coconut plots (Maheswarappa et al., 2008). During decomposition of organic manure, various organic acids will be produced, which solubilize phosphates and other phosphate bearing minerals, thereby lowering the phosphate fixation and increasing availability. Manna et al. (2006) reported that available phosphorus content increased due to the addition of FYM over initial and control. The organic matter also forms a cover on sesquioxides. It makes them inactive and thus reduces the phosphate fixing capacity of the soil, which ultimately helps in the release of an ample quantity of phosphorus (Bhardwaj et al., 2010).

Higher available $\mathrm{P}_{2} \mathrm{O}_{5}$ content was observed in surface $(0-30 \mathrm{~cm})$ in coconut soils and ranged from 4.1 to $64.4 \mathrm{~kg} \mathrm{ha}^{-1}$ with a mean of $21.82 \mathrm{~kg} \mathrm{ha}^{-1}$. In arecanut soils, available $\mathrm{P}_{2} \mathrm{O}_{5}$ at the surface $\left(0-30 \mathrm{~cm}\right.$ depth) varied from 5.9 to $33.1 \mathrm{~kg} \mathrm{ha}^{-1}$ with a mean of $17.71 \mathrm{~kg} \mathrm{ha}^{-1}$. Available $\mathrm{P}_{2} \mathrm{O}_{5}$ was the least in the depth of $90-120 \mathrm{~cm}$ in both arecanut and coconut soils in ACZs. The declining trend in available $\mathrm{P}_{2} \mathrm{O}_{5}$ with depth was observed in soils of all zones. There was a significant difference in available $\mathrm{P}_{2} \mathrm{O}_{5}$ among depths and zone, crops and zone in the soil.

\section{Available $\mathrm{K}_{2} \mathrm{O}$}

The maximum amount of available $\mathrm{K}_{2} \mathrm{O}$ content was recorded in arecanut $\left(151.71 \mathrm{~kg} \mathrm{ha}^{-1}\right)$ compared to coconut $\left(110.1 \mathrm{~kg} \mathrm{ha}^{-1}\right)$. In arecanut soils, available $\mathrm{K}_{2} \mathrm{O}$ content ranged from 66.8 to 511.7 $\mathrm{kg} \mathrm{ha}^{-1}$ in the surface and 48.4 to $308.5 \mathrm{~kg} \mathrm{ha}^{-1}$ in the sub-surface. Available $\mathrm{K}_{2} \mathrm{O}$ content in coconut soils varied from 79.4 to $233.6 \mathrm{~kg} \mathrm{ha}^{-1}$ and 37.6 to 461.2 $\mathrm{kg} \mathrm{ha}^{-1}$ in surface and subsurface, respectively (Table 5).

Available $\mathrm{K}_{2} \mathrm{O}$ levels in coconut and arecanut plantations were in the order of $\mathrm{STZ}>\mathrm{EDZ}>\mathrm{CZ}>$ $\mathrm{SDZ}>\mathrm{HZ}$ and $\mathrm{STZ}>\mathrm{SDZ}>\mathrm{HZ}>\mathrm{EDZ}>\mathrm{CZ}$, respectively. Among the zones, irrespective of crops, STZ recorded higher available $\mathrm{K}_{2} \mathrm{O}\left(228.1 \mathrm{~kg} \mathrm{ha}^{-1}\right)$ followed by SDZ (124.5 $\left.\mathrm{kg} \mathrm{ha}^{-1}\right)$, EDZ (155.3 $\left.\mathrm{kg} \mathrm{ha}^{-1}\right)$, HZ (77.5 $\left.\mathrm{kg} \mathrm{ha}^{-1}\right)$ and CZ (69.0 kg ha $\left.{ }^{-1}\right)$. Available $\mathrm{K}_{2} \mathrm{O}$ was the lowest in coastal zone (laterite) soils due to heavy rainfall ( $>3000 \mathrm{~mm}$ ) and topography, which accentuate the process of leaching of nutrients resulting in poor nutrient retention capacity, and these soils are poor in bases of native soil fertility with abundant sesquioxides (Babu,1981). The deficiency of nitrogen and potassium is due to the dominant clay mineral kaolinite, which has a low $\mathrm{K}$ fixation capacity (Badrinath et al., 1998). Available nitrogen and potassium were significantly $(\mathrm{P}<0-05)$ lower in soil under coconut plantations compared with double fruit crops (Manna and Singh, 2001).

In general, higher available $\mathrm{K}_{2} \mathrm{O}$ was observed in surface $(0-30 \mathrm{~cm})$, and with increasing depth to the extent of $187.9,143.5,103.7$ and $88.5 \mathrm{~kg} \mathrm{ha}^{-1}$ for $0-30 \mathrm{~cm}, 30-60 \mathrm{~cm}, 60-90 \mathrm{~cm}$ and $90-120 \mathrm{~cm}$, respectively. There was a significant difference between depths, zone and crop zone for available $\mathrm{K}_{2} \mathrm{O}$. At the same time, the interaction effect for crop depth and zone depth and crop $\times$ zone $\times$ depth was found to be non-significant.

\section{Conclusion}

The fertility status of coconut and arecanut growing soils of different agro-climatic zones of Karnataka indicated that soils are low to medium in available $\mathrm{N}$ and $\mathrm{K}$ in surface and sub-surface. The soils were low in available phosphorus due to high $P$ fixing capacity and also removal than replenishment. Higher available $\mathrm{N}_{\text {and }} \mathrm{K}_{2} \mathrm{O}$ were observed in arecanut soils than coconut soils. However, hilly and coastal zone have higher nitrogen than other zones due to higher biomass addition. Soils from STZ have higher inherent available $\mathrm{K}_{2} \mathrm{O}$ related to mixed clay mineralogy.

\section{References}

Achalu, C., Heluf, G., Kibebew, K. and Abi, T. 2012. Effects of liming on acidity-related chemical properties of soils of different land use systems in Western Oromia, Ethiopia: World Journal of Agriculture Science 8: 560-567.

Babu, P. V. L. P. 1981. Laterite as an Unconformity Plane in the Evolution of the Indian Peninsula - A Synthesis. Oxford \& IBH Publishing Co., New Delhi, pp. 237-245.

Badrinath, M. S., Chidanandappa, H. M., Ali, .Mir K. and Chamegowda, T. C., 1995. Impact of lime on rice yield and available potassium in coastal acid soils of Karnataka. Agropedology 5: 43-46. 
Badrinath, Gajendragad, M. R. and Balakrishna Rao, K. 1998. Distribution of micronutrients in laterite soils of Puttur in relation to some soil properties. In: Red and Lateritic soils Volume 1. (Eds. Sehgal, J., Blum, W. E. and Gajbhiye, K. S.) Oxford \& IBH Publishing Co., New Delhi pp. 271-274.

Bhardwaj A. K., McLaughlin R. A., Shainberg I., Levy G. J. (2009) Polyacrylamide effect on flocculation and hydraulic properties of depositional seals made of different clays. Soil Science Society of America Journal 73: 910-918.

Bhat, R. and Sujatha, S. 2007. Soil fertility status as inûuenced by arecanut based cropping system and nutrient management. Journal of Plantation Crops 35: 158-165.

Bhat, R. and Sujatha, S. 2014. Soil fertility status and disorders in arecanut (Areca catechu L.) grown on clay and laterite soils of India. Communications in Soil Science and Plant Analysis 45: 1622-1635.

Jackson, M. L. 1973. Soil Chemical Analysis Prentice Hall of India Pvt. Ltd., New Delhi, 498.

Maheswarappa, H. P., 2008. In-situ waste management in integrated nutrient management system under coconut (Cocos nucifera) based high density multi-species cropping system in tropical soils of India. Indian Journal of Agricultural Sciences 78 (11): 924 -928.

Manna, K. K., Brar, B. S. and Dhillon, N. S., 2006. Influence of long-term use of FYM and inorganic fertilizers on nutrient availability in a Typic Ustochrept. Indian Journal of Agricultural Sciences 76 (8): 477-480.

Manna, M. C., and Singh, M. V., 2001. Long-term effects of intercropping and bio-litter recycling on soil biological activity and fertility status of sub-tropical soils. Bioresource Technology 76: 143-150.

Page, A. L., Miller, R. H. and Keeney, D. R., 1982. Methods of Soil Analysis. Part 2. American Society of Agronomy and Soil Science Society of America, Madison.

Perur, N. G., 1996. Acid soils of Karnataka. In: Acid Soils of India, Mahapatra, I. C., Mandal, S. C., Misra, C., Mitra, G. N., Panda, N. (Eds.), Indian Council of Agricultural Research, New Delhi, pp. 165-173.

Saikh, H., Varadachari, C. and Ghosh, K., 1998. Effect of deforestation and cultivation on soil CEC and contents of exchangeable bases: A case study in Simlipal National Park, India. Plant and Soil 204: 175-181.

Singh, G., Single, S. K. and Reddy, L. S., 2013. Check list of commercial varieties of plantation crops, Published by Department of Agriculture Cooperation \& Farmers Welfare. Ministry of Agriculture, Krishi Bhawan, New Delhi.

Subbiah, B. V. and Asija, G. L., 1956. A rapid procedure for estimation of available nitrogen in soils. Current Science 25: 259-260.

Sujatha, S., Bhat, R. and Pallem, C., 2015. Recycling potential of organic wastes of arecanut and cocoa in India: A short review. Environmental Technology Reviews, 4: 91-102.

Walkley, A., and Black. C. A., 1934. Estimation of organic carbon by chromic acid titration method. Soil Science 37: 29-38.

West, L. T., Beinroth, F. H., Summer, M. F. and Kang, B. T., 1997. Ultisols: Characteristics and impact on society. Advances in Agronomy 63: 179-126. 